\title{
SEWAGE SLUDGE APPLICATIONS FOR ENHANCING GROWTH OF SOME EUCALYPTUS SPECIES GROWN IN NEW RECLAIMED SANDY SOIL
}

\author{
M.M.E. AbdEl-Kader \\ Forestry Department Research, Hort. Research Institute, Agriculture \\ Research Center, Giza, Egypt.
}

\begin{abstract}
This study was carried out at the Experimental Farm of ElKassasin Hort. Research Station, Hort. Research Institute, Agriculture Research Center, Giza, Egypt, during the two successive seasons of 2008/09 and 2009/10 aiming to evaluate the effect of sewage sludge on growth and chemical composition of some Eucalyptus species (E. citriodora, E. gomphocphala and E. camaldulensis) grown under sandy soil conditions. Sewage sludge was mixed with the sandy medium at five levels of 0,10,20,30 and $40 \%(w / w)$ before plantation.

Obtained results indicated that $E$. gomphocphala gave significant increments in all growth parameters; i.e., plant height and stem diameter as well as fresh and dry weights of leaves, stem and roots per plant compared to E. camaldulensis and E. citriodora,. In addition, E. camaldulensis recorded the highest percentages of $N, P$ and $K$ in different plant organs.

Seedlings planted in mixture containing $30 \%$ sewage sludge + $70 \%$ sandy soil, generally, had the highest increments in all growth parameters, uptake and total uptake of N, P and K. Also, level $40 \%$ sewage sludge (mixture medium contain $40 \%$ sewage sludge $+60 \%$ sandy soil) resulted high values of $N, P$ and $K \%$ in plant organs.

Regarding the interaction treatments, the highest values of the above mentioned growth parameters, uptake, and total uptake of $N, P$ and $K$ in plant organs were recorded in E. gomphocephala planted in mixture medium $30 \%$ sewage sludge $+70 \%$ sandy soil. Also, plantation of E. camaldulensis in mixture medium containing $40 \%$ sewage sludge $+60 \%$ sandy soil recorded high percentages of $N, P$ and $K$ in plant organs in most cases.

Therefore, it could be recommend that planting Eucalyptus plants especially E. gomphocephala in new reclaimed sandy soils amended with sewage sludge at rate of 30 or $40 \%$. Since, these combined treatments enhanced plant growth and its uptake of the main essential elements (NPK) and permit a good chance to reduce or eliminate the risk of the
\end{abstract}


environmental pollution resulted from sewage sludge. Also, E. camaldulensis and E. citriodora can be resulted satisfactory growth in sandy soils amended with sewage sludge.

Key words: Sewage sludge, enhancing growth, eucalyptus species, New Reclaimed Sandy soil.

\section{INTRODUCTION}

Eucalyptus species (Fam: Myrtaceae) naturally occur in all Australian mainland status (Hall et al., 1970). They have bean widely planted over seas in areas with Mediterranean climate. However, Eucalyptus species are believed to be introduced into Egypt in the 1800's (El-Lakany et al., 1980). They are highly adapted to the local environmental conditions and grow very fast. These species are traditionally planted as windbreak, for shade and to supply wood for lumber, particle board and charcoal production.

In Egypt, huge amount of sewage sludge (also refereed as biosolids) resulted daily. The raped increase of population, urban planning and the industrial developments resulted more accumulation of it. Additionally, it causes a great environmental problem because the derived risk from the presence of pathogens, heavy metals and organic pollutants in sludge (Harrison et al., 2006).

The cultivated area in Egypt exist around the Nile valley and the delta (4\% of the total Egypt area), the remaining 96\% are desert soil (sandy or calcareous). This soil is lacking organic matter and nutrients. The industrial development and the necessity for desert reclamation to increase the agriculture production to feed the growing population have increased the burden on fertilizer and water resources. It is must to reuse non-conventional water resources (urban sewage water) for irrigation and sludge as organic fertilizer after proper treatment. As a consequence, there is an urgent need for conservation and reuse of wastewater. However, the reuse of sewage water and sludge without proper treatment is the main source of environmental pollution. Proper treatments should be applied before the reuse can take place (ElMotaium, 2006)

Use of sewage sludge (biosolid) as a fertilizer or soil conditioner is the best recycling option from agriculture and environmental view point. Sludge has many advantages in improving soil fertility and increasing crop production (Kumazawa, 1997). Sludge provides the soil with organic matter, nutrients and improves the soil water holding capacity and cations exchange capacity. In addition, the sewage sludge application improves the soil structure and fertility (Cuevas et al., 2000 and Mata-Gonzalez et al., 2002). However, sludge fertilizer frequently used in agriculture in many countries for enhancing plants 
growth and reduce the environmental pollution (Spinosa, 2007). Previous researches proved the enhancing effects of sludge fertilizer on plant growth rate (plant height, stem diameter and fresh and dry weights of plant organs) and increased contents of N, P and $\mathrm{K}$ in plant tissues (Androde and Mattizzo, 2000 on Eucalyptus grandis; El-Baha, 2001 on E. camaldulensis; Ya et al., 2001 on Sesbania rostrata and S. connabina; Wang et al., 2004 on Pinus rasiata and El-Settawy and El-Harriry, 2009 on Acacia saligna, Casuarina glauca and Eucalyptus camaldulensis). Also, plant organic matter was increased after sewage sludge applications (Wang et al., 2008).

Therefore, this work aimed to evaluate effects of sewage sludge (biosolids) on growth and mineral uptake of some Eucalyptus species grown under sandy soil conditions to determine to what extant $E$. species can be utilize from these biosolids in their growth under new reclaimed sandy soils.

\section{MATERIALS AND METHODS}

This study was carried out at the Experimental Farm of El-Kassasin Hort. Research Station, Hort. Research Institute, Agriculture Research Center, Giza, Egypt , during the two successive growing seasons of 2008/09 and 2009/10 aiming to study effects of sewage sludge (biosolids) on growth and mineral uptake of some Eucalyptus species grown under sandy soil conditions to determine to what extant E. species can be utilize from these biosolids in their growth under new reclaimed sandy soils.

The experimental layout was factorial experiment between three Eucalyptus species and five sewage sludge levels, so the experiment was implicated fifteen treatments. These treatments were arranged as a split plot in a randomized complete block design with three replicates, each replicate contained six plants (six polyethylene bags, each contain one plant). E. species were randomly assigned in the main plots, while the sewage sludge levels were randomly arranged in the sub- plots.

The three tested Eucalyptus species were E. citriodora L. (Limon scented spotted gum), E. gomphocephala Dehn (Turat) and E. camaldulensis Dehn (River-redgum or Murrary red gum). They were purchased from a commercial nursery as a uniform transplants aged one year old on March $1^{\text {st }}$ for the two tested seasons.

Treatment bulks of sewage sludge were supplied by Ismailia Waste Water Station at Sarabium. Chemical and physical properties of the used sewage sludge are shown in Table 1. It was used only once by mixing it with the sandy medium before Eucalyptus transplanting. The five tested levels of sewage sludge were $0,10,20,30$ or $40 \%$ (W/ W).

On March $1^{\text {st }}$ during the two tested seasons, sewage sludge at the above mentioned levels were mixed with sandy soil (analyzed as: $83.0 \%$ sand, $7.9 \mathrm{pH}, 0.62 \%$ organic matter, 123 ppm N, 199 ppm P and 144 ppm K). 
Table 1: Chemical and physical analysis of the used dry sewage sludge

\begin{tabular}{|l|c|cc|}
\hline Parameters & Value & \multicolumn{2}{|c|}{$\begin{array}{c}\text { Total heavy metals } \\
(\mathbf{p p m})\end{array}$} \\
\hline Organic matter & 24.55 & $\mathbf{F e}$ & 92.5 \\
\hline Organic carbon & 13.25 & $\mathbf{M n}$ & 166 \\
\hline Total nitrogen & 2.20 & $\mathbf{Z n}$ & 258 \\
\hline C/N ratio & 7.20 & $\mathbf{C u}$ & 735 \\
\hline Available phosphorus & 1.30 & $\mathbf{C d}$ & 3 \\
\hline Total potassium & 0.48 & $\mathbf{N i}$ & 42 \\
\hline pH (1:2.5 sludge : water) & 7.9 & $\mathbf{P b}$ & 201 \\
\hline E.C $(\mathbf{1 : 1}$ sludge $:$ water, $\mathbf{d s} / \mathbf{m})$ & 3.6 & & \\
\hline
\end{tabular}

Then, the uniform Eucalyptus transplants were transplanted in $17 \times 25 \mathrm{~cm}$ black polyethylene bags (capacity $8 \mathrm{~kg}$ sandy soil), one transplant/ bag. After that, bags were set under lathe house conditions for 15 days, then transferred to the open conditions and all normal agriculture practices were done when ever needed until the end of experiment on March $1^{\text {st }} 2009$ and 2010 for the $1^{\text {st }}$ and $2^{\text {nd }}$ seasons, respectively (one year after planting).

\section{Recorded data:}

On March $1^{\text {st }} 2009$ and 2010 for the $1^{\text {st }}$ and $2^{\text {nd }}$ seasons, respectively at the end of experiment (one year after planting), responses of eucalyptus plant were evaluated as follows:

1. Vegetative growth: Vegetative growth responses was recorded as plant height $(\mathrm{cm})$, main stem diameter at base of the main stem $(\mathrm{mm})$ and fresh and dry weights of leaves, stems and roots/ plant (g). In addition total plant fresh and dry weights were calculated.

2. Chemical determinations: Leaf, stem and root samples for chemical analysis were taken. They were dried at $70^{\circ} \mathrm{C}$ for 72 hours, finely ground and wet digested. Total nitrogen percentage was colorimetrically determined according to A.O.A.C (1980), and phosphorus percentage was determined according to Olsen and Sommers (1982), as well as potassium percentage was determined using flame photometer according to the method of Chapman and Pratt (1961). Then, N, P and K uptake by different plant organs (roots stem and leaves) were calculated ( $\mathrm{mg} / \mathrm{kg}$ dry weight).

3. Translocation factor (TF) of $N, P$ and $K$ within plant organs: Translocation factor (TF) as ratio of the above mentioned elements from root to stem (element \% in stem tissues/ element \% in root tissues) and from root 
to leaves (element \% in leaves/ element \% in root) was calculated according to Ghorab (2005).

\section{Statistical analysis:}

Collected data were subjected to statistical analysis according to Steel and Torrie (1980). Mean separation was done using least significant difference (L.S.D) at 5\% level.

\section{RESULTS AND DISCUSSION}

\section{Vegetative growth:}

\subsection{Plant height and stem diameter}

Presented data in Table 2 revealed that Eucalyptus gomphocephala recorded the tallest plants $\left(166.73\right.$ and $155.33 \mathrm{~cm}$ for $1^{\text {st }}$ and $2^{\text {nd }}$ seasons, respectively) and had the highest value of stem diameter $(73.70$ and $75.23 \mathrm{~mm}$ for $1^{\text {st }}$ and $2^{\text {nd }}$ seasons, respectively) compared to other species. This was true during the two tested seasons. The differences among the studied species may be due to the heredity differences which reflected on their vegetative growth.

As for sewage sludge, plantation of eucalyptus seedling in mixture medium containing $30 \%$ sewage sludge plus $70 \%$ sandy soil gave the tallest plant height ( 195.33 and $176.44 \mathrm{~cm}$ ) and recorded the maximum stem diameter ( 83.22 and $79.38 \mathrm{~mm}$ ) comparing to the other tested mixture media in the two seasons (Table 2).

Regarding the interaction between plant species and sewage sludge levels, data of the same Table 2 showed that the greatest values for both plant height and stem diameter were recorded in E. gomphocephala planted in mixture medium containing $30 \%$ sewage sludge $+70 \%$ sandy soil $(205.00$ and $193.33 \mathrm{~cm}$ and 87.33 and $86.50 \mathrm{~mm}$ in the $1^{\text {st }}$ and $2^{\text {nd }}$ seasons, respectively) as compared to other interaction treatments.

The enhancing effect of sewage sludge on eucalyptus plant growth may be due to that sewage sludge had abundant from organic matter as well as N, P and $\mathrm{K}$ elements (Table 1). However, such results are in agreement with those found by Yost et al. (1987) on Eucalyptus saligna, Androde and Mattizzo (2000) on E. Grandis and El- Baha (2001) on E. camaldulensis with respect sewage sludge. They reported that using sewage sludge gave higher values of growth parameters.

\subsection{Fresh and dry weights of leaves, stem and roots per plant}

Data in Tables 3 clear that there were significant effects among plant species, sewage sludge applications and their interactions on eucalyptus plant growth represented as fresh and dry weights of different plant organs. 
Table 2. Effect of plant species, sewage sludge and their interactions on plant height and stem diameter of Eucalyptus species during 2008/09 and 2009/10 seasons

\begin{tabular}{|c|c|c|c|c|c|}
\hline \multirow{2}{*}{\multicolumn{2}{|c|}{$\begin{array}{ll}\text { Treatments } & \text { Characters } \\
\end{array}$}} & \multicolumn{2}{|c|}{ Plant height (cm) } & \multicolumn{2}{|c|}{ Stem diameter $(\mathbf{m m})$} \\
\hline & & $\begin{array}{c}1^{\text {st }} \\
\text { Season }\end{array}$ & $\begin{array}{c}2^{\text {nd }} \\
\text { Season }\end{array}$ & $\begin{array}{c}1^{\text {st }} \\
\text { Season }\end{array}$ & $\begin{array}{c}2^{\text {nd }} \\
\text { Season }\end{array}$ \\
\hline \multicolumn{6}{|c|}{ Effect of Eucalyptus species: } \\
\hline \multicolumn{2}{|l|}{ E. citriodora } & 127.46 & 114.63 & 68.56 & 60.36 \\
\hline \multicolumn{2}{|l|}{ E. gomphocephala } & 166.73 & 155.23 & 73.70 & 75.23 \\
\hline \multicolumn{2}{|l|}{ E. camaldulensis } & 151.16 & 144.86 & 69.83 & 67.96 \\
\hline \multicolumn{2}{|l|}{ LSD at 0.05 level } & 6.43 & 5.18 & 1.099 & 0.70 \\
\hline \multicolumn{6}{|c|}{ Effect of sewage sludge levels*: } \\
\hline \multicolumn{2}{|l|}{$0 \%$} & 90.27 & 87.88 & 55.13 & 54.61 \\
\hline \multicolumn{2}{|l|}{$10 \%$} & 123.94 & 119.55 & 63.33 & 62.05 \\
\hline \multicolumn{2}{|l|}{$20 \%$} & 157.61 & 149.11 & 74.69 & 70.16 \\
\hline \multicolumn{2}{|l|}{$30 \%$} & 195.33 & 176.44 & 83.22 & 79.38 \\
\hline \multicolumn{2}{|l|}{$40 \%$} & 175.11 & 158.22 & 77.11 & 73.05 \\
\hline \multicolumn{2}{|l|}{ LSD at 0.05 level } & 5.66 & 3.36 & 2.01 & 1.66 \\
\hline \multicolumn{6}{|c|}{ Effect of interaction between Eucalyptus species and sewage sludge levels: } \\
\hline \multicolumn{6}{|c|}{\begin{tabular}{|l|ll|l|l|l|l|} 
& $\mathbf{0}$ & $\%$ & 72.50 & 76.16 & 52.25 & 49.66 \\
\end{tabular}} \\
\hline \multirow{4}{*}{ E. citriodora } & $10 \%$ & 100.00 & 97.00 & 62.16 & 56.00 \\
\hline & $20 \%$ & 129.50 & 118.33 & 73.08 & 61.66 \\
\hline & $30 \%$ & 186.00 & 155.00 & 80.00 & 71.66 \\
\hline & $40 \%$ & 149.33 & 126.66 & 75.33 & 62.83 \\
\hline \multirow{5}{*}{ E. gomphocephala } & $0 \%$ & 106.00 & 97.50 & 57.16 & 59.00 \\
\hline & $10 \%$ & 145.00 & 135.00 & 66.33 & 68.33 \\
\hline & $20 \%$ & 181.00 & 169.33 & 77.00 & 79.66 \\
\hline & $30 \%$ & 205.00 & 193.33 & 87.33 & 86.50 \\
\hline & $40 \%$ & 196.66 & 181.00 & 80.66 & 82.66 \\
\hline \multirow{5}{*}{ E. camaldulensis } & $0 \%$ & 92.33 & 90.00 & 56.00 & 55.16 \\
\hline & $10 \%$ & 126.83 & 126.66 & 61.50 & 61.83 \\
\hline & $20 \%$ & 162.33 & 159.66 & 74.00 & 69.16 \\
\hline & $30 \%$ & 195.00 & 181.00 & 82.33 & 80.00 \\
\hline & $40 \%$ & 179.33 & 167.00 & 75.33 & 73.66 \\
\hline \multicolumn{2}{|l|}{ LSD at 0.05 level } & 9.80 & 5.69 & $\mathbf{3 . 5 0}$ & 2.86 \\
\hline
\end{tabular}

* Sewage sludge was applied by mixing it at different tested rates with the sandy planting medium before eucalyptus seedling transplanting. 
Eucalyptus gomphocephala recorded the highest values of fresh weight of leaves (360.10 and $361.00 \mathrm{~g})$, stem (987.68 and $986.71 \mathrm{~g}$ ) and roots (460.23 and $463.03 \mathrm{~g}$ ) in $1^{\text {st }}$ and $2^{\text {nd }}$ seasons, respectively. Also, the same species recorded the highest values of dry weight of leaves (180.41 and $180.06 \mathrm{~g}$ ) stem $(594.65$ and $593.13 \mathrm{~g})$ and roots $(232.96$ and $239.83 \mathrm{~g})$ in the $1^{\text {st }}$ and $2^{\text {nd }}$ seasons, respectively as compared to other species.

As for sewage sludge, recorded results in Table 3 showed that plantation eucalyptus plant in mixture medium containing $30 \%$ sewage sludge $+70 \%$ sandy soil resulted the highest values of fresh weight and dry weights of leaves, stem and roots/ plant comparing to the other tested levels of sewage sludge during the two seasons.

In regard to the interaction treatments (Table 3), the highest values of fresh weight of leaves (578.33 and $582.33 \mathrm{~g}$ ), stem (1591.41 and $1558.50 \mathrm{~g}$ ) and roots $(800.00$ and $806.50 \mathrm{~g})$ were obtained by planting of $E$. gomphocephala in mixture medium contain sewage sludge at $30 \%$ and sandy soil at $70 \%$. Also the same interaction treatment gave the highest values of dry weight of leaves (288.00 and $289.50 \mathrm{~g}$ ), stem (967.08 and $957.24 \mathrm{~g}$ ) and roots (403.50 and $405.00 \mathrm{~g}$ ) comparing to the other combination treatments. This was confirmed in the two seasons (Table 2).

Generally, plant growth is defined as an irreversible increase in volume. Growth is usually measured in terms of changes in fresh and dry weights of the living tissues over a particular period of time (Taiz and Zeiger, 2007). However, Androde and Mattizzo (2000) on E. Grandis, El- Baha (2001) on E. camaldulensis, Abd El-Kader (2006) on pine seedling and Lazdi et al. (2007) on willow plant found that using sewage sludge at different levels gave the better biomass. According to Stein (1997), most seedlings species grow faster in soil treated with sewage sludge; and some species respond dramatically, while others show only a slight response. Greater growth responses have been seen when seedlings have planted directly in soil already amended with large amounts of sewage sludge.

\section{Chemical Determinations:}

\section{2. $N, P$ and $K$ percentages in different plant organs}

Results presented in Tables ( 4 \& 5) showed significant differences respecting N, P and $\mathrm{K} \% \mathrm{~s}$ in plant organs of different Eucalyptus species under study in both seasons. E. camaldulensis recoded the highest values of N, P and $\mathrm{K} \% \mathrm{~s}$ in stem ( 1.94 and $1.89 \%$ for $\mathrm{N}, 0.101$ and $0.097 \%$ for $\mathrm{P}, 1.42$ and 1.42 $\%$ for $\mathrm{K}$ in the $1^{\text {st }}$ and $2^{\text {nd }}$ seasons , respectively), leaf ( 2.69 and $2.58 \%$ for $\mathrm{N}$, 0.114 and $0.117 \%$ for $\mathrm{P}$ and 1.81 and $1.87 \%$ for $\mathrm{K}$ in the $1^{\text {st }}$ and $2^{\text {nd }}$ seasons, respectively), and root tissues ( 2.40 and $2.37 \%$ for N, 0.114 and $0.113 \%$ for $\mathrm{P}, 1.67$ and $1.72 \%$ for $\mathrm{K}$ in the $1^{\text {st }}$ and $2^{\text {nd }}$ seasons, respectively). 
Table 4. Effect of plant species, sewage sludge applications and their interactions on $\mathrm{N}, P$ and $K$ percentages in different plant organs of Eucalyptus species during 2008/ 09 season

\begin{tabular}{|c|c|c|c|c|c|c|c|c|c|c|}
\hline \multirow{2}{*}{\multicolumn{2}{|c|}{$\begin{array}{l}\text { Characters } \\
\text { Treatments }\end{array}$}} & \multicolumn{3}{|c|}{$\mathbf{N}(\%)$} & \multicolumn{3}{|c|}{$\mathbf{P}(\%)$} & \multicolumn{3}{|c|}{$\mathbf{K}(\%)$} \\
\hline & & Stem & Leaves & oots & em & Leaves & oots & tem & Leaves & $\operatorname{Rog}$ \\
\hline \multicolumn{11}{|c|}{ Effect of Eucalyptus species: } \\
\hline \multicolumn{2}{|l|}{ E. citriod } & 1.38 & .53 & 01 & 9 & 096 & 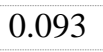 & 1.29 & 1.66 & 1.62 \\
\hline \multicolumn{2}{|c|}{ E. gomphocephala } & 78 & .59 & & 096 & 104 & (2) & 31 & 1.73 & 66 \\
\hline \multicolumn{2}{|l|}{ E. camaldulensis } & 1.94 & 2.69 & 40 & 101 & .114 & 114 & .42 & 1.81 & 1.67 \\
\hline \multicolumn{2}{|l|}{ LSD at 0.55 level } & $\mathbf{0 . 0 2}$ & 0.07 & & 2 & 0.002 & 010 & 0.04 & 0.02 & NS \\
\hline \multicolumn{11}{|c|}{ Effect of sewage sluc } \\
\hline \multicolumn{2}{|l|}{$0 \%$} & 1.00 & 2.06 & 1.5 & 0.079 & .090 & .085 & 1.03 & 1.25 & 1.21 \\
\hline \multicolumn{2}{|l|}{$10 \%$} & 5 & 2.20 & & 37 & 097 & 94 & 14 & 1.40 & 1.35 \\
\hline \multicolumn{2}{|l|}{$20 \%$} & 1.7 & 2. & & & 3 & 9 & 29 & 68 & 1.57 \\
\hline \multicolumn{2}{|l|}{$30 \%$} & 0 & 3. & & & 5 & & & .10 & 2.03 \\
\hline \multicolumn{2}{|l|}{$40 \%$} & 2 & 3.0 & 2. & 1 & .120 & .120 & 79 & 2.23 & 2.11 \\
\hline \multicolumn{2}{|l|}{ LSD at 0.5 level } & 0.08 & 0.05 & 0.08 & 0.026 & 0.003 & 0.005 & 5 & 0.04 & 0.07 \\
\hline \multicolumn{11}{|c|}{ Effect of interaction between Eucalyptus species and sewage sludge levels: } \\
\hline \multirow{5}{*}{ E. citriodora } & $0 \%$ & 0.77 & 1.99 & 126 & 0068 & 0.083 & 0.079 & 0.94 & 1.23 & 1.20 \\
\hline & & 0.97 & & & & 0 & & & 1.32 & 1.29 \\
\hline & $20 \%$ & 1.2 & 2.57 & 2. & 38 & 0.091 & 0.086 & 26 & 1.67 & 1.60 \\
\hline & $30 \%$ & 1.87 & 2.98 & 2. & 3 & 0.109 & .108 & .41 & 2.02 & 1.96 \\
\hline & $40 \%$ & 2.0 & $3 .($ & & & 0.114 & 10 & .72 & 2.10 & 2.08 \\
\hline \multirow{5}{*}{$\begin{array}{c}E . \\
\text { gomphocephala }\end{array}$} & $\mathbf{0}$ & 1.0 & 2.0 & & 7 & 0.090 & 079 & .02 & 1.24 & 1.19 \\
\hline & $10 \%$ & 1.7 & 2.1 & & 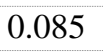 & 0.099 & 0.094 & 1.11 & 1.42 & 1.36 \\
\hline & $20 \%$ & 1.97 & 2.64 & 2. & 0.101 & 0.103 & 0.096 & 1.30 & 1.67 & 1.59 \\
\hline & $30 c$ & 2.0 & $3 .($ & 2. & 10 & 0.113 & 0.110 & 1.42 & 2.07 & 2.08 \\
\hline & 40 & 2.0 & $3 .($ & 2. & & 0.116 & .115 & 1.72 & 2.24 & 2.10 \\
\hline \multirow{5}{*}{$\begin{array}{c}\text { E. } \\
\text { camaldulensis }\end{array}$} & & 1.1 & 2.1 & & & 0.097 & 0.097 & 1.12 & 1.30 & 1.23 \\
\hline & $10 \%$ & 1.84 & 2.3 & 1.5 & 96 & 0.106 & .104 & .20 & 1.47 & 1.40 \\
\hline & $20 \%$ & 2.16 & 2.74 & 2.34 & 0.100 & 0.115 & 0.116 & 1.32 & 1.71 & 1.53 \\
\hline & 30 & 2.28 & 3.11 & 2.9 & 0.104 & 0.124 & 0.119 & 1.55 & 2.21 & 2.06 \\
\hline & $40 \%$ & 2.27 & 3.13 & 2.9 & 0.110 & 0.129 & 0.136 & 1.93 & 2.36 & 2.16 \\
\hline \multicolumn{2}{|l|}{ LSD at 0.5 level } & 0.14 & 0.10 & 0.14 & 0.046 & 0.006 & 0.009 & NS & 0.07 & NS \\
\hline
\end{tabular}

* Sewage sludge was applied by mixing it at different tested rates with the sandy planting medium before eucalyptus seedling transplanting.

The differences among Eucalyptus species could be attributed to the genetic differences between them.

Also, results of the same Tables 4 and 5 revealed that mixing sewage sludge with the sandy soil resulted significant increases in N, P and K \%s in different eucalyptus plant organ tissues as compared to control treatment during the two tested seasons. The highest percentages of these elements were 
Table 5. Effect of plant species, sewage sludge applications and their interactions on $N, P$ and $K$ percentages in different plant organs of Eucalyptus species during 2009/10 season

\begin{tabular}{|c|c|c|c|c|c|c|c|c|c|c|}
\hline \multirow{2}{*}{\multicolumn{2}{|c|}{ Treatments }} & \multicolumn{3}{|c|}{$\mathbf{N}(\%)$} & \multicolumn{3}{|c|}{$\mathbf{P}(\%)$} & \multicolumn{3}{|c|}{$\bar{K}(\%)$} \\
\hline & & Stem & Leaves & Roots & Stem & Leaves & Roots & Stem & Leaves & Roots \\
\hline \multicolumn{11}{|c|}{ Effect of Eucalyptus species: } \\
\hline \multicolumn{2}{|c|}{ E. citriodora } & 1.41 & 2.52 & 2.07 & 0.090 & 0.099 & 0.107 & 1.25 & 1.64 & 1.56 \\
\hline \multicolumn{2}{|c|}{ E. gomphocephala } & 1.75 & 2.53 & 2.25 & 0.095 & 0.104 & 0.115 & 1.29 & 1.75 & 1.52 \\
\hline \multicolumn{2}{|c|}{ E. camaldulensis } & 1.89 & 2.58 & 2.37 & 0.097 & 0.117 & 0.113 & 1.42 & 1.87 & 1.72 \\
\hline \multicolumn{2}{|c|}{ LSD at 0.55 level } & 0.06 & 0.02 & 0.03 & 0.002 & 0.015 & 0.005 & 0.06 & 0.04 & 0.04 \\
\hline \multicolumn{11}{|c|}{ Effect of sewage sludge levels*: } \\
\hline \multicolumn{2}{|c|}{$0 \%$} & 1.03 & 2.07 & 1.64 & 0.077 & 0.090 & 0.092 & 1.04 & 1.23 & 1.17 \\
\hline \multicolumn{2}{|c|}{$10 \%$} & 1.47 & 2.19 & 1.85 & 0.084 & 0.098 & 0.107 & 1.14 & 1.41 & 1.29 \\
\hline \multicolumn{2}{|c|}{$20 \%$} & 1.75 & 2.61 & 2.17 & 0.096 & 0.104 & 0.113 & 1.27 & 1.71 & 1.55 \\
\hline \multicolumn{2}{|c|}{$30 \%$} & 2.06 & 2.90 & 2.71 & 0.104 & 0.117 & 0.122 & 1.44 & 2.16 & 1.88 \\
\hline \multicolumn{2}{|c|}{$40 \%$} & 2.09 & 2.96 & 2.77 & 0.109 & 0.123 & 0.123 & 1.72 & 2.25 & 2.10 \\
\hline \multicolumn{2}{|c|}{ LSD at 0.5 level } & 0.05 & 0.04 & 0.06 & 0.003 & 0.004 & 0.005 & 0.03 & 0.04 & 0.05 \\
\hline \multicolumn{11}{|c|}{ Effect of interaction between Eucalyptus species and sewage sludge levels: } \\
\hline \multirow{5}{*}{$\begin{array}{c}E . \\
\text { citriodor } \\
a\end{array}$} & $0 \%$ & 0.87 & 2.01 & 1.32 & 0.072 & 0.083 & 0.084 & 0.99 & 1.15 & 1.11 \\
\hline & $10 \%$ & 0.98 & 2.13 & 1.51 & 0.078 & 0.089 & 0.099 & 1.09 & 1.30 & 1.25 \\
\hline & $20 \%$ & 1.25 & 2.55 & 2.05 & 0.089 & 0.092 & 0.106 & 1.20 & 1.66 & 1.55 \\
\hline & $30 \%$ & 1.93 & 2.96 & 2.67 & 0.101 & 0.107 & 0.120 & 1.38 & 2.02 & 1.89 \\
\hline & $40 \%$ & 2.02 & 2.97 & 2.81 & 0.110 & 0.122 & 0.123 & 1.59 & 2.08 & 2.00 \\
\hline \multirow{5}{*}{$\begin{array}{c}E . \\
\text { gomphoce } \\
\text { phala }\end{array}$} & $0 \%$ & 1.05 & 2.06 & 1.77 & 0.075 & 0.088 & 0.096 & 1.02 & 1.23 & 1.16 \\
\hline & $10 \%$ & 1.64 & 2.15 & 1.99 & 0.083 & 0.100 & 0.110 & 1.14 & 1.43 & 1.25 \\
\hline & $20 \%$ & 1.93 & 2.61 & 2.16 & 0.099 & 0.104 & 0.117 & 1.29 & 1.71 & 1.50 \\
\hline & $30 \%$ & 2.05 & 2.92 & 2.66 & 0.107 & 0.114 & 0.126 & 1.40 & 2.13 & 1.67 \\
\hline & $40 \%$ & 2.06 & 2.95 & 2.68 & 0.110 & 0.115 & 0.127 & 1.62 & 2.24 & 2.02 \\
\hline \multirow{5}{*}{$\begin{array}{c}E . \\
\text { camaldul } \\
\text { ensis }\end{array}$} & 0 \% & 1.18 & 2.14 & 1.84 & 0.085 & 0.100 & 0.096 & 1.12 & 1.31 & 1.26 \\
\hline & $10 \%$ & 1.81 & 2.28 & 2.07 & 0.090 & 0.105 & 0.110 & 1.19 & 1.50 & 1.38 \\
\hline & $20 \%$ & 2.07 & 2.68 & 2.31 & 0.099 & 0.117 & 0.117 & 1.31 & 1.76 & 1.60 \\
\hline & $30 \%$ & 2.20 & 2.84 & 2.81 & 0.104 & 0.128 & 0.120 & 1.56 & 2.32 & 2.08 \\
\hline & $40 \%$ & 2.20 & 2.96 & 2.84 & 0.107 & 0.133 & 0.120 & 1.94 & 2.44 & 2.28 \\
\hline \multicolumn{2}{|c|}{ LSD at 0.5 level } & 0.10 & 0.07 & 0.10 & 0.005 & 0.006 & NS & 0.06 & 0.07 & 0.09 \\
\hline
\end{tabular}

* Sewage sludge was applied by mixing it at different tested rates with the sandy planting medium before eucalyptus seedling transplanting.

recorded in tissues of plants grown in sandy soil containing $40 \%$ sewage sludge (2.13 and $2.09 \%$ for N, 0.111 and $0.109 \%$ for P and 1.79 and $1.72 \%$ for $\mathrm{K}$ in stem; 3.06 and $2.96 \%$ for N, 0.120 and $0.123 \%$ for $\mathrm{P}$ and 2.23 and $2.25 \%$ for $\mathrm{K}$ in leaves; as well as 2.82 and $2.77 \%$ for $\mathrm{N}, 0.120$ and $0.123 \%$ 
for $\mathrm{P}$ and 2.11 and $2.10 \%$ for $\mathrm{K}$ in roots during $1^{\text {st }}$ and $2^{\text {nd }}$ seasons, respectively).

For the interaction treatments (eucalyptus plant species $\mathrm{X}$ sewage sludge levels), it could be observed that E. camaldulensis plant grown in mixture medium containing $40 \%$ sewage sludge plus $60 \%$ sandy soil had the highest percentages of $\mathrm{N}, \mathrm{P}$ and $\mathrm{K}$ in stem, leaves and roots compared to the all other interaction treatments. This was confirmed during the two tested seasons (Tables 4 \& 5).

\subsection{Uptake and total uptake of nitrogen}

Data in Table 6 show that there were significant differences among the three tested eucalyptus species for uptake and total uptake of nitrogen in plant organs in the two seasons. Eucalyptus gomphocephala had the highest values of $\mathrm{N}$ uptake in stem $\left(11.487\right.$ and $11.299 \mathrm{~g} / \mathrm{Kg} \mathrm{DW}$ in the $1^{\text {st }}$ and $2^{\text {nd }}$ seasons, respectively) compared to other plant organs. Also, it is recorded the highest mean value of total $\mathrm{N}$ uptake per plant $\left(22.225\right.$ and $21.886 \mathrm{~g} / \mathrm{kg} \mathrm{DW}$ in the $1^{\text {st }}$ and $2^{\text {nd }}$ seasons, respectively).

Plantation of eucalyptus in sandy soil containing $30 \%$ sewage sludge resulted the highest values of $\mathrm{N}$ uptake in all plant organs ( 14.511 and 14.218 $\mathrm{g} / \mathrm{kg}$ DW in stem, 7.294 and $6.923 \mathrm{~g} / \mathrm{kg}$ DW in leaves, 7.705 and $7.571 \mathrm{~g} / \mathrm{kg}$ DW in roots in the $1^{\text {st }}$ and $2^{\text {nd }}$ seasons, respectively).

Also results of interaction between Eucalyptus gomphocephala and plantation in $30 \%$ sewage sludge $+70 \%$ sandy soil (Table 6 ) showed higher values of $\mathrm{N}$ uptake in stem, roots and leaves, respectively (19.758 and $19.616 \mathrm{~g} /$ $\mathrm{kg}$ DW for stem, 8.812 and $8.453 \mathrm{~g} / \mathrm{kg}$ DW for leaves, as well as 11.121 and $10.785 \mathrm{~g} / \mathrm{kg} \mathrm{DW}$ in roots in the $1^{\mathrm{st}}$ and $2^{\text {nd }}$ seasons, respectively) and total $\mathrm{N}$ uptake in both seasons (39.691and $38.856 \mathrm{~g} / \mathrm{kg} \mathrm{DW})$.

\subsection{Uptake and total uptake of phosphorus}

Data in Table 7 reveal that there were significant differences among eucalyptus species in most cases. However, E. gomphocephala recorded high $\mathrm{P}$ uptake in stem $(0.605$ and $0.597 \mathrm{mg} / \mathrm{kg} \mathrm{DW})$ and total P uptake/ plant (1.051 and $1.050 \mathrm{mg} / \mathrm{kg} \mathrm{DW}$ ) for $1^{\text {st }}$ and $2^{\text {nd }}$ seasons, respectively. The variability among the studied species might be due to the heredity differences

Plantation plants in sandy soil containing $30 \%$ sewage sludge recorded the highest values of $\mathrm{P}$ uptake in different plant organs and total $\mathrm{P}$ uptake for two seasons $(0.718$ and $0.711 \mathrm{~g} / \mathrm{kg}$ DW in stem, 0.277 and $0.282 \mathrm{~g} / \mathrm{kg}$ DW in leaves and 0.320 and $0.331 \mathrm{~g} / \mathrm{kg}$ DW in roots and 1.316 and $1.325 \mathrm{~g} / \mathrm{kg} \mathrm{DW}$ ) for total uptake in the $1^{\text {st }}$ and $2^{\text {nd }}$ seasons, respectively (Table 7).

For interaction treatments (Table 7), E. gomphocephala planted in mixture of sewage sludge at $30 \%+$ sandy soil at $70 \%$ had the highest values 
Table 6. Effect of plant species, sewage sludge applications and their interactions on $\mathbf{N}$ uptake by different plant organs and total uptake/ plant (g /kg DW) of Eucalyptus species during 2008/09 and 2009/10 seasons

\begin{tabular}{|c|c|c|c|c|c|c|c|c|c|}
\hline \multirow{3}{*}{\multicolumn{2}{|c|}{ Treatments }} & \multicolumn{6}{|c|}{ N uptake (g/ kg DW) } & \multirow{2}{*}{\multicolumn{2}{|c|}{$\begin{array}{c}\text { Total N uptake } \\
\text { (g/ kg DW) }\end{array}$}} \\
\hline & & \multicolumn{2}{|c|}{ Stem } & \multicolumn{2}{|c|}{ Leaves } & \multicolumn{2}{|c|}{ Root } & & \\
\hline & & $\begin{array}{c}1^{\text {st }} \\
\text { Season }\end{array}$ & $\begin{array}{c}2^{\text {nd }} \\
\text { Season }\end{array}$ & $\begin{array}{c}1^{\text {st }} \\
\text { Season }\end{array}$ & $\begin{array}{c}2^{\text {nd }} \\
\text { Season }\end{array}$ & $\begin{array}{l}1^{\text {st }} \\
\text { eason }\end{array}$ & $\begin{array}{c}2^{\text {nd }} \\
\text { Season }\end{array}$ & $\begin{array}{c}1^{\text {st }} \\
\text { Season }\end{array}$ & $\begin{array}{c}2^{\text {nd }} \\
\text { Season }\end{array}$ \\
\hline \multicolumn{10}{|c|}{ Effect of Eucalyptus species: } \\
\hline & 2.587 & 2.575 & 539 & 453 & 165 & 281 & 291 & .311 \\
\hline \multicolumn{2}{|c|}{ E. gomphocephala } & 11.487 & 11.299 & 4.965 & 019 & 772 & .767 & 225 & 1.886 \\
\hline \multicolumn{2}{|c|}{ E. camaldulensis } & 10.685 & 10.503 & 984 & 00 & 843 & 790 & 13 & 9.994 \\
\hline \multicolumn{2}{|c|}{ LSD at 0.05 level } & 0.620 & 0.351 & 0.416 & 64 & 075 & .371 & & .527 \\
\hline \multicolumn{10}{|c|}{ Effect of sewage sludge levels*: } \\
\hline \multicolumn{2}{|l|}{$0 \%$} & 1.725 & 1.856 & 1.518 & 497 & 1.203 & 1.335 & .447 & 4.688 \\
\hline \multicolumn{2}{|l|}{$10 \%$} & 4.777 & 4.701 & 308 & 254 & .880 & .230 & 966 & 9.186 \\
\hline \multicolumn{2}{|l|}{$20 \%$} & 8.197 & 8.035 & 4.121 & 024 & .112 & .091 & 5.431 & 15.151 \\
\hline \multicolumn{2}{|l|}{$30 \%$} & .511 & 14.218 & 7.294 & 23 & 705 & 571 & 10 & 28.713 \\
\hline \multicolumn{2}{|l|}{$40 \%$} & 12.056 & 11.819 & 5.572 & 8 & 734 & 504 & 62 & 22.581 \\
\hline \multicolumn{2}{|c|}{ LSD at 0.05 level } & 0.356 & 0.297 & 0.266 & 0.210 & 0.249 & 0.298 & & 0.516 \\
\hline \multicolumn{10}{|c|}{ Effect of interaction between Eucalyptus species and sewage sludge levels: } \\
\hline \multirow{5}{*}{ E. citriodora } & $0 \%$ & 0.727 & 0.832 & 1.160 & 1.154 & 0.449 & 0.581 & 2.337 & 2.568 \\
\hline & $10 \%$ & 1.263 & 1.270 & 1.794 & 737 & 0.677 & 0.735 & & 3.742 \\
\hline & $20 \%$ & 2.353 & 2.357 & 2.372 & 2.206 & 1.173 & 1.201 & 5.900 & 5.765 \\
\hline & $30 \%$ & 4.421 & 4.523 & 4.370 & 6 & 1.856 & 2.094 & 10.647 & 10.924 \\
\hline & $40 \%$ & 4.170 & 3.894 & 2.997 & 864 & 1.670 & 1.796 & 8.838 & 8.555 \\
\hline \multirow{5}{*}{$\begin{array}{l}\text { E. } \\
\text { gomphocephala }\end{array}$} & $0 \%$ & 2.284 & 2.275 & 1.719 & 696 & 1.624 & 1.766 & 5.627 & 5.738 \\
\hline & $10 \%$ & 6.833 & 6.595 & 2.663 & 2.700 & 2.870 & 3.677 & 12.367 & 12.973 \\
\hline & $20 \%$ & 11.457 & 11.151 & 5.012 & 4.984 & 4.586 & 4.415 & 21.057 & 20.550 \\
\hline & $30 \%$ & 19.758 & 19.616 & 8.812 & 8.453 & 11.121 & 10.785 & 39.691 & 38.856 \\
\hline & $40 \%$ & 17.104 & 16.861 & 6.620 & 6.264 & 8.661 & 8.190 & 32.386 & 31.315 \\
\hline \multirow{5}{*}{$\begin{array}{l}\text { E. } \\
\text { camaldulensis }\end{array}$} & $0 \%$ & 2.165 & 2.461 & 1.674 & 1.640 & 1.535 & 1.656 & 5.375 & 5.758 \\
\hline & $10 \%$ & 6.236 & 6.239 & 2.467 & 2.325 & 2.094 & 2.278 & 10.797 & 10.843 \\
\hline & $20 \%$ & 10.780 & 10.596 & 4.979 & 4.883 & 3.577 & 3.656 & \begin{tabular}{|l|}
19.337 \\
\end{tabular} & 19.137 \\
\hline & $30 \%$ & 19.353 & 18.515 & 8.699 & 8.009 & 10.138 & 9.835 & 38.192 & 36.359 \\
\hline & $40 \%$ & 14.894 & 14.701 & 7.099 & 1.154 & 6.869 & 6.525 & 28.863 & 27.873 \\
\hline \multicolumn{2}{|c|}{ LSD at 0.05 level } & 0.615 & 0.518 & 0.460 & 0.364 & 0.432 & 0.516 & 0.700 & 0.894 \\
\hline
\end{tabular}

* Sewage sludge was applied by mixing it at different tested rates with the sandy planting medium before eucalyptus seedling transplanting. 
Table 7. Effect of plant species, sewage sludge applications and their interactions on $\mathbf{P}$ uptake by different plant organs and total uptake/ plant (g /kg DW) of Eucalyptus species during 2008/09 and 2009/10 seasons

\begin{tabular}{|c|c|c|c|c|c|c|c|c|c|}
\hline \multirow{3}{*}{\multicolumn{2}{|c|}{ Treatments }} & \multicolumn{6}{|c|}{ P uptake $(g /$ kg DW) } & \multirow{2}{*}{\multicolumn{2}{|c|}{$\begin{array}{c}\text { Total P } \\
\text { uptake (g/ kg } \\
\text { DW) }\end{array}$}} \\
\hline & & \multicolumn{2}{|c|}{ Stem } & \multicolumn{2}{|c|}{ Leaves } & \multicolumn{2}{|c|}{ Roo } & & \\
\hline & & $\begin{array}{c}1^{\text {st }} \\
\text { Season }\end{array}$ & $\begin{array}{c}2^{\text {nd }} \\
\text { Season } \\
\end{array}$ & $\begin{array}{c}1^{\text {st }} \\
\text { Season } \\
\end{array}$ & $\begin{array}{c}2^{\text {nd }} \\
\text { Season } \\
\end{array}$ & $\begin{array}{c}1^{\text {st }} \\
\text { Season }\end{array}$ & $\begin{array}{c}2^{\text {nd }} \\
\text { Season } \\
\end{array}$ & $\begin{array}{c}1^{\text {st }} \\
\text { Season }\end{array}$ & $\begin{array}{c}2^{\text {nd }} \\
\text { Season } \\
\end{array}$ \\
\hline \multicolumn{10}{|c|}{ Effect of Eucalyptus species: } \\
\hline \multicolumn{2}{|l|}{ E. citriodora } & 0.159 & 0.157 & 0.095 & 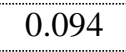 & .054 & .059 & 0.309 & 0.310 \\
\hline \multicolumn{2}{|c|}{ E. gomphocephala } & 0.605 & 0.597 & 0.193 & 94 & 252 & 259 & 1.051 & .050 \\
\hline \multicolumn{2}{|c|}{ E. camaldulensis } & 0.520 & 0.515 & 0.207 & 11 & 220 & .228 & 0.947 & 0.955 \\
\hline \multicolumn{2}{|c|}{ LSD at 0.05 level } & 0.038 & 0.013 & 0.013 & 10 & 013 & 0.018 & 0.031 & 0.025 \\
\hline \multicolumn{10}{|c|}{ Effect of sewage sludge levels*: } \\
\hline \multicolumn{2}{|l|}{$0 \%$} & 0.133 & 0.135 & 0.066 & 065 & .066 & .071 & 0.265 & 0.272 \\
\hline \multicolumn{2}{|l|}{$10 \%$} & 0.254 & 0.248 & 0.102 & 101 & .099 & .114 & 0.456 & 0.464 \\
\hline \multicolumn{2}{|l|}{$20 \%$} & 0.415 & 0.414 & 0.162 & 163 & 0.146 & 0.149 & 0.724 & 0.727 \\
\hline \multicolumn{2}{|l|}{$30 \%$} & .718 & 0.711 & .277 & 2 & 320 & 331 & .316 & .325 \\
\hline \multicolumn{2}{|l|}{$40 \%$} & 0.620 & 0.606 & 0.218 & 20 & 244 & .245 & 1.083 & 1.071 \\
\hline \multicolumn{2}{|c|}{ LSD at 0.05 level } & 0.020 & 0.019 & 0.009 & 0.010 & 0.010 & 0.016 & 0.019 & 0.026 \\
\hline \multicolumn{10}{|c|}{ Effect of interaction between Eucalyptus species and sewage sludge levels: } \\
\hline \multirow{5}{*}{ E. citriodora } & & 0.063 & 0.068 & 0.048 & 0.047 & 0.029 & 0.036 & 0.141 & 0.152 \\
\hline & $10 \%$ & 0.102 & 0.100 & 0.072 & 0.072 & 0.041 & 0.043 & 0.216 & 0.216 \\
\hline & $20 \%$ & 0.164 & 0.168 & 0.084 & 0.079 & 0.052 & 0.053 & 0.301 & 0.301 \\
\hline & $30 \%$ & 0.242 & 0.235 & 0.159 & .156 & 0.077 & 0.084 & 0.479 & 0.476 \\
\hline & $40 \%$ & 0.224 & 0.212 & 0.113 & 0.117 & 0.069 & 0.078 & 0.407 & 0.408 \\
\hline \multirow{5}{*}{$\begin{array}{l}\text { E. } \\
\text { gomphocephala }\end{array}$} & 0 $\%$ & 0.164 & 0.162 & 0.075 & 072 & 0.084 & 0.088 & 0.324 & 0.322 \\
\hline & $10 \%$ & 0.336 & 0.333 & 0.122 & 0.125 & 0.146 & 0.184 & 0.605 & 0.643 \\
\hline & $20 \%$ & 0.583 & 0.568 & 0.194 & 0.197 & 0.211 & 0.211 & 0.989 & 0.977 \\
\hline & $30 \%$ & 1.028 & 1.027 & 0.325 & 0.330 & 0.456 & 0.461 & 1.809 & 1.818 \\
\hline & $40 \%$ & 0.916 & 0.894 & 0.250 & 0.244 & 0.362 & 0.351 & 1.530 & 1.490 \\
\hline \multirow{5}{*}{$\begin{array}{l}\text { E. } \\
\text { camaldulensis }\end{array}$} & $0 \%$ & 0.172 & 0.176 & 0.075 & 0.076 & 0.084 & 0.089 & 0.332 & 0.343 \\
\hline & $10 \%$ & 0.325 & 0.310 & 0.112 & 0.106 & 0.111 & 0.115 & 0.548 & 0.532 \\
\hline & $20 \%$ & 0.499 & 0.506 & 0.208 & 0.212 & 0.175 & 0.184 & 0.883 & 0.903 \\
\hline & $30 \%$ & 0.884 & 0.872 & 0.346 & 0.361 & 0.429 & 0.449 & 1.660 & 1.683 \\
\hline & $40 \%$ & 0.720 & 0.710 & 0.292 & 0.297 & 0.300 & 0.305 & 1.313 & 1.314 \\
\hline \multicolumn{2}{|c|}{ LSD at 0.05 level } & 0.034 & $\mathbf{0 . 0 3 3}$ & 0.015 & 0.017 & 0.017 & 0.028 & $\mathbf{0 . 0 3 3}$ & 0.046 \\
\hline
\end{tabular}

* Sewage sludge was applied by mixing it at different tested rates with the sandy planting medium before eucalyptus seedling transplanting. 
of $\mathrm{P}$ uptake in stem for two seasons ( 1.028 and $1.027 \mathrm{~g} / \mathrm{kg} \mathrm{DW}$ ) and total uptake (1.809 and $1.818 \mathrm{~g} / \mathrm{kg} \mathrm{DW})$.

\subsection{Uptake and total uptake of potassium}

Tabulated results in Table 8 show that the highest value of $\mathrm{K}$ uptake in stem was recorded in E. gomphocephala $\left(8.412\right.$ and $8.178 \mathrm{~g} / \mathrm{kg} \mathrm{DW}$ in the $1^{\text {st }}$ and $2^{\text {nd }}$ seasons, respectively). Also, the same specie recorded the highest value of total uptake of K (16.065 and $15.482 \mathrm{~g} / \mathrm{kg} \mathrm{DW}$ in the 1 sat and $2^{\text {nd }}$ seasons, respectively). These differences in minerals uptake among the three species might be mainly due to the heredity differences.

Plantation of seedlings in mixture of sewage sludge at $30 \%+$ sandy soil at $70 \%$ recorded the highest value of K uptake in all plant organs ( 10.090 and $9.937 \mathrm{~g} / \mathrm{kg}$ DW for stem, 5.042 and $5.222 \mathrm{~g} / \mathrm{kg} \mathrm{DW}$ in leaves, 5.631 and $5.187 \mathrm{~g} / \mathrm{kg} \mathrm{DW}$ in roots in the $1^{\text {st }}$ and $2^{\text {nd }}$ seasons, respectively), also the same mixture medium recorded higher total $\mathrm{K}$ uptake ( Table 8).

The interaction between E. gomphocephala and plantation in mixture medium of $40 \%$ sewage sludge $+60 \%$ sandy soil (Table 8 ) gave the highest values of K uptake in stem, ( 14.092 and $13.267 \mathrm{~g} / \mathrm{kg} \mathrm{DW}$ in the $1^{\text {st }}$ and $2^{\text {nd }}$ seasons, respectively) and total $\mathrm{K}$ uptake $\left(28.176 \mathrm{~g} / \mathrm{kg} \mathrm{DW}\right.$ in the $1^{\text {st }}$ season). While the interaction between E. camaldulensis and plantation in sandy soil containing sewage sludge at $30 \%$ gave the highest total $\mathrm{K}$ uptake in the $2^{\text {nd }}$ season only ( $27.033 \mathrm{~g} / \mathrm{kg} \mathrm{DW})$.

However, such results are in agreement with those obtained by Talli and Riipera (1996) determining N, P and K contents in some ornamental trees; Androde and Mattizzo (2000) on Eucalyptus grandis applying sewage sludge at 10, 20 and 40 ton/ $h a$ and determined $\mathrm{N}$ concentration in leaves; Ya et al. (2001) recorded total N, P and K in plant tissues of Sesbania rostrata and S. cannabian; and El-Settawy and El-Harriry (2009) on some woody trees, evaluated $\mathrm{N}, \mathrm{P}$ and $\mathrm{K}$ percentages in leaf tissues . They concluded that sewage sludge applications significantly increased N, P and K content in plant organs.

\section{Translocation factor (TF) ratio of $\mathbf{N}, \mathbf{P}$ and $\mathrm{K}$ within plant organs}

Data in Table 9 showed that, E. citriodora recorded highest value of translocation factor (TF) of nitrogen in leaves (1.32 and 1.26) in the $1^{\text {st }}$ and $2^{\text {nd }}$ seasons, respectively). While E. gomphocephala recorded the highest values of TF of $\mathrm{P}$ in leaves (1.062) in the $1^{\text {st }}$ season and TF of $\mathrm{K}$ in leaves (1.14) in the $2^{\text {nd }}$ season.

Plantation of eucalyptus seedling in $100 \%$ sandy soil without sewage sludge recorded the highest value of TF of $\mathrm{N}$ in leaves ( 1.32 and $1.28 \%$ in the $1^{\text {st }}$ and $2^{\text {nd }}$ seasons, respectively) and highest value of phosphorus $\mathrm{TF}$ (1.070 in the $1^{\text {st }}$ season only). On the other hand, plantation of seedlings in 
Table 8. Effect of plant species, sewage sludge applications and their interactions on $\mathrm{K}$ uptake by different plant organs and total uptake/ plant (g /kg DW) of Eucalyptus species during 2008/09 and 2009/10 seasons

\begin{tabular}{|c|c|c|c|c|c|c|c|c|c|}
\hline \multirow{3}{*}{\multicolumn{2}{|c|}{ Treatments }} & \multicolumn{6}{|c|}{ K uptake (g/ kg DW) } & \multirow{2}{*}{\multicolumn{2}{|c|}{$\begin{array}{c}\text { Total K uptake } \\
\text { (g/ kg DW) }\end{array}$}} \\
\hline & & \multicolumn{2}{|c|}{ Stem } & \multicolumn{2}{|c|}{ Leaves } & \multicolumn{2}{|c|}{ Root } & & \\
\hline & & $\begin{array}{c}1^{\text {st }} \\
\text { Season }\end{array}$ & $\begin{array}{c}2^{\text {nd }} \\
\text { Season }\end{array}$ & $\begin{array}{c}1^{\text {st }} \\
\text { Season }\end{array}$ & $\begin{array}{c}\mathbf{2}^{\text {nd }} \\
\text { Season }\end{array}$ & $\begin{array}{c}1^{\text {st }} \\
\text { Season }\end{array}$ & $\begin{array}{c}2^{\text {nd }} \\
\text { Season }\end{array}$ & $\begin{array}{c}1^{\text {st }} \\
\text { Season }\end{array}$ & $\begin{array}{c}2^{\text {nd }} \\
\text { Season }\end{array}$ \\
\hline \multicolumn{10}{|c|}{ Effect of Eucalyptus species: } \\
\hline \multicolumn{2}{|l|}{ E citriodora } & 2.315 & 2.184 & 1.684 & 1.622 & 0.927 & 0.954 & 4.927 & 4.760 \\
\hline \multicolumn{2}{|c|}{ E. gomphocephala } & 8.412 & 8.178 & 3.362 & 3.403 & 4.281 & 3.900 & 16.056 & 15.482 \\
\hline \multicolumn{2}{|c|}{ E. camaldulensis } & 7.717 & 7.866 & 3.438 & 3.557 & 3.405 & 3.544 & 14.562 & 14.968 \\
\hline \multicolumn{2}{|c|}{ LSD at 0.05 level } & 0.569 & 0.372 & 0.282 & 0.114 & 0.359 & 0.248 & 0.753 & 0.659 \\
\hline \multicolumn{10}{|c|}{ Effect of sewage sludge levels*: } \\
\hline \multicolumn{2}{|l|}{ 0 \% } & 1.726 & 1.833 & 0.923 & 0.893 & 0.872 & 0.926 & 3.522 & 3.652 \\
\hline \multicolumn{2}{|l|}{$10 \%$} & 3.311 & 3.367 & 1.479 & 1.463 & 1.369 & 1.476 & 6.160 & 6.306 \\
\hline \multicolumn{2}{|l|}{$20 \%$} & 5.517 & 5.484 & 2.603 & 2.640 & 2.183 & 2.166 & 10.305 & 10.291 \\
\hline \multicolumn{2}{|l|}{$30 \%$} & 10.090 & 9.937 & 5.042 & 5.222 & 5.631 & 5.187 & 20.765 & 20.348 \\
\hline \multicolumn{2}{|l|}{$40 \%$} & 10.096 & 9.760 & 4.093 & 4.085 & 4.300 & 4.242 & 18.489 & 18.088 \\
\hline \multicolumn{2}{|c|}{ LSD at 0.05 level } & 0.309 & 0.296 & 0.189 & 0.142 & 0.243 & 0.206 & 0.437 & 0.288 \\
\hline \multicolumn{10}{|c|}{ Effect of interaction between Eucalyptus species and sewage sludge levels: } \\
\hline \multirow{5}{*}{$\begin{array}{c}E . \\
\text { citriodora }\end{array}$} & $\mathbf{0} \%$ & 0.886 & 0.950 & 0.714 & 0.659 & 0.429 & 0.487 & 2.030 & 2.097 \\
\hline & $10 \%$ & 1.436 & 1.416 & 1.116 & 1.057 & 0.624 & 0.608 & 3.178 & 3.083 \\
\hline & $20 \%$ & 2.373 & 2.267 & 1.541 & 1.441 & 0.922 & 0.908 & 4.836 & 4.617 \\
\hline & $30 \%$ & 3.336 & 3.222 & 2.957 & 2.948 & 1.385 & 1.481 & 7.679 & 7.653 \\
\hline & $40 \%$ & 3.543 & 3.065 & 2.091 & 2.004 & 1.275 & 1.284 & 6.910 & 6.353 \\
\hline \multirow{5}{*}{$\begin{array}{l}\text { E. } \\
\text { gomphocephal }\end{array}$} & $0 \%$ & 2.191 & 2.209 & 1.043 & 1.011 & 1.118 & 1.157 & 4.354 & 4.379 \\
\hline & $10 \%$ & 4.425 & 4.570 & 1.769 & 1.799 & 2.016 & 2.295 & 8.210 & 8.665 \\
\hline & $20 \%$ & 7.554 & 7.445 & 3.166 & 3.276 & 3.287 & 3.065 & 14.008 & 13.787 \\
\hline & $30 \%$ & 13.797 & 13.402 & 5.983 & 6.166 & 8.395 & 6.788 & 28.176 & 26.357 \\
\hline & $40 \%$ & 14.092 & 13.267 & 4.850 & 4.763 & 6.588 & 6.194 & 25.531 & 24.225 \\
\hline \multirow{5}{*}{$\begin{array}{c}E . \\
\text { camaldulensis }\end{array}$} & $0 \%$ & 2.100 & 2.339 & 1.011 & 1.008 & 1.069 & 1.133 & 4.181 & 4.481 \\
\hline & $10 \%$ & 4.072 & 4.114 & 1.552 & 1.531 & 1.467 & 1.524 & 7.092 & 7.170 \\
\hline & $20 \%$ & 6.624 & 6.740 & 3.103 & 3.203 & 2.341 & 2.526 & 12.070 & 12.470 \\
\hline & $30 \%$ & 13.137 & 13.188 & 6.187 & 6.553 & 7.113 & 7.291 & 26.438 & 27.033 \\
\hline & $40 \%$ & 12.652 & 12.948 & 5.338 & 5.490 & 5.037 & 5.247 & 23.028 & 23.685 \\
\hline \multicolumn{2}{|c|}{ LSD at 0.05 level } & $\mathbf{0 . 5 3 7}$ & 0.512 & 0.329 & 0.245 & 0.420 & 0.357 & 0.757 & 0.499 \\
\hline
\end{tabular}

* Sewage sludge was applied by mixing it at different tested rates with the sandy planting medium before eucalyptus seedling transplanting. 
of seedlings in mixture of sewage sludge at $30 \%+$ sand at $70 \%$ gave the higher TF of $\mathrm{K}$ in leaves (1.15 in $2^{\text {nd }}$ season only).

As for interaction effects (Table 9), E. citriodora planted in $100 \%$ sandy soil recorded the highest value of nitrogen TF in leaves (1.57 and 1.51 in the $1^{\text {st }}$ and $2^{\text {nd }}$ seasons, respectively). While, plantation E. camaldulensis in the same medium (without sewage sludge) gave the highest value of $\mathrm{P}$ TF in stem ( 0.075 and 0.068 in the $1^{\text {st }}$ and $2^{\text {nd }}$ seasons, respectively). The interaction between the tested eucalyptus species $X$ all sewage sludge application levels had no significant effect on TF of $\mathrm{K}$ in stem and leaves in both seasons.

Conclusively, it could be recommend that planting eucalyptus plants especially E. gomphocephala in new reclaimed sandy soils with using sewage sludge at rate of 30 or $40 \%$ (mixing with soil w/w) as untraditional fertilizer. This practice enhance plant growth and its uptake of the main essential elements (NPK) and permit a good chance to reduce or eliminate the risk of the environmental pollution resulted from sewage sludge.

\section{REFERENCES}

A.O.A.C. (1980). Official Methods of Analysis. $12^{\text {th }}$ Ed. Association of Official Analytical Chemists. Washington. D.C., U.S.A.

Abdel-Kader, M.M.E.(2006). Effect of sewage sludge and chemical fertilizer on growth and element content of pine seedlings cultivated under reclaimed sandy soil conditions. Egypt. Journal of Appl. Science, 21:639-654.

Androde, C.A.De and M.E.Mattizzo (2000). Nitrates and heavy metals in soil and in trees after application of sewage sludge (biosolids) on Eucalyptus grandis. Scientia- Forestalis, Vol. 58:59-72.

Chapman, H.D. and P.F. Pratt. (1961). Methods of Analysis for Soil, Plants and Water. University California, Div. Of Agric. Sci., USA.

Cuevas, G., R. Blázquez, F. Martinez and I. Walter. (2000). Composted MSW effects on soil properties and native vegetation in a degraded semiarid shrubland. Compost Science and Utilization, 8: 303- 309.

El-Baha, A.M. (2001). Response of Eucalyptus camaldulensis affected by thinning and sewage sludge or inorganic fertilizer on a poor quality site. Alex. J. Agric. Res., 46 (1):269-295.

El-Lakany, m., L.M.El-Osta and O.A. Badran (1980). Evaluation of newly introduced Eucalyptus camaldulensis provinces in Egypt. Alex. J. Agric. Res., 28 (3):309-319.

El-Motaium, R.A. (2006). Application of nuclear techniques in environmental studies and pollution control. Proceedings of the 2nd Environmental Physics Conference, 18-22 Feb. Alexandria, Egypt, pp169-182. 
El-Settawy, A.A.A. and M.F.M. El-Harriry (2009). Study on the effect of sewage sludge amendment on growth and yield of some woody trees, dynamic of AM. Fungi and bioextraction- remediation of trees. $J$. Agriculture Science, Mansoura University, 34 (6):7435-7453.

Ghorab, S.A.S. (2005). Growth, biomass yield and heavy metals accumulation by seedlings of five trees species irrigated with waste water and the role of VAM in heavy metals bioremediation. Ph.D. Thesis, Faculty Agriculture, Alex. University, Egypt.

Hall, N., R.D. Johnston and J.M. Chippendale. (1970). For trees of Australia, P100-101. Australian Government Publishing service Canberra, Australia.

Harrison, E.Z., S.R.Oakes, M.Hysell and A. Hay. (2006). Organic cemical in sewage sludge. Science of the total environment, 367 (2-3):481-497.

Kumazawa K. (1997). Use of sewage sludge for agriculture in Japan. Proceedings of consultants meetings on sewage sludge and wastewater for use in agriculture. Oct. 1997. 199 pp. 111-127. Joint FAO/IAEA Div. of Nuclear Techniques in Food and Agriculture, Vienna- Austria, International Atomic Energy Agency

Lazdi, D., A. Lazdins , Z.Karins and V.Kaposts . (2007). Effect of sewage sludge fertilization in shoor-rotation Willow plantations. J. Environ. Eng. And Land. Mang. , 15 (2):105-111.

Mata-González, R., R. Sosebee and C. Wan. (2002). Shoot and root biomass of desert grasses as affected by biosolids application. Journal of Arid Environments, 50: 477-488.

Olsen, S.R. and L.E. Sommers. (1982). Phosphorus. In: Page, A.L., R.H. Miller and D.R. Keeney (eds).Methods of Soil Analysis. Part 2, Amer. Soc. Agron. Madison, W.I. USA pp. 403 - 430.

Spinosa, L. (2007). Wastewater Sludge : A global overview of the current status and future prospects. IWA Publishing London, 41pp.

Steel, R. and S.Torrie (1980). Principle And Procedure Of Statistics. Second edition. Mc Grow-Mil Inc. N.Y.P.16-22.

Stein, 1. (1997). Land application of Biosolids : Process Design Manual States Environmental Protection Agency. Office of Science and Technology, pp290.

Taiz, L. and e. Zeiger (2007). A Companion to Plant Physiology. $4^{\text {th }}$ edition, on line.

Talli, P. and Riipera (1996). Using sewage sludge when growing ornamented tees and shrubs. Metsanduslkud-Unrimussed, 27:102-111. 
Wang, H. G.N. Mogeson, M.O. Kimberley, T.W. Payn, P.J. Wilks and C.R. Fisher.(2004). Environmental and nutrimental responses of Pinus radiate plantation to biosolids application. Plant and Soil , 267 (12):255-262.

Wang, T., G. Yinghua and J. Yongfeng (2008). Studies and land application of sewage sludge and its limiting factors. J. Hazardous Materials, 160(2-3) 30 December: 554-558.

Ya, Z.H., Z.Y. Yang, G.Y.Z. Chan and m.H. Wang (2001). Growth response of Sesbania rostrata and S. cannubiona to sludge amended lead, zinc mine talings : A green house study. Environmental International, 26 (516):449-455.

Yost, R.S., D.S. Debell, C.D. Whitesell and S. Miyasaka (1987). Early growth and nutrient status of Eucalyptus saligan as affected by nitrogen and phosphorus fertilization. Australian Forest Research, 17(3):203214.

\section{استخدام الحمأة لدفع نمو بعض أنواع الكافور النامية في أراض رملية حديثة الاستصلاح أنواع}

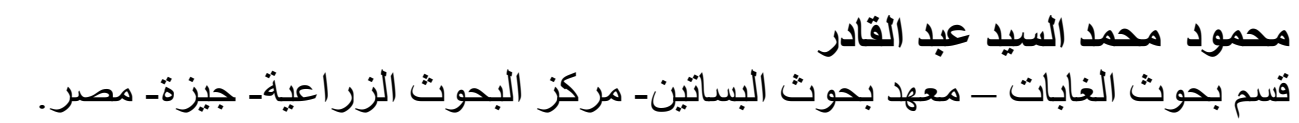

أجرى هذا البحث في المزرعة التجريبية لمحطة بحوث البساتين

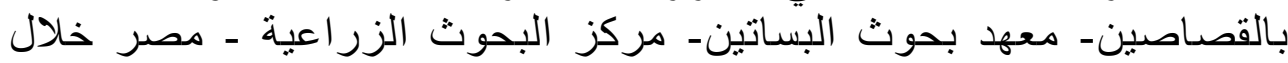

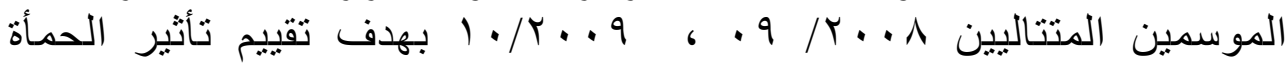

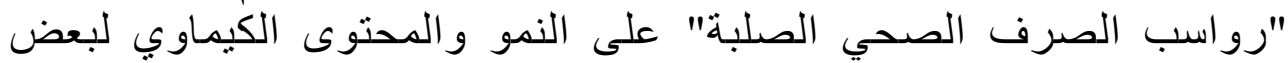

، E. Eomphocphala ، Eucalyptus citriodora) أنواع الكافور ب. camaldulensis

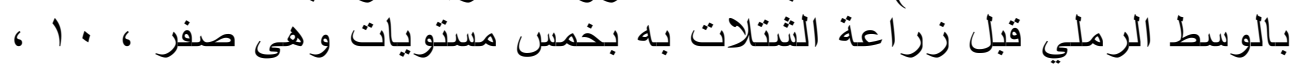

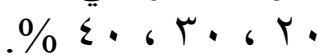

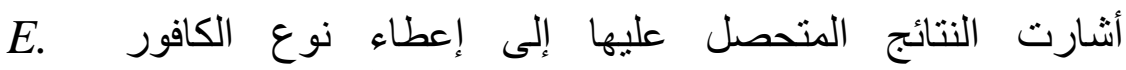
زوomphocphala

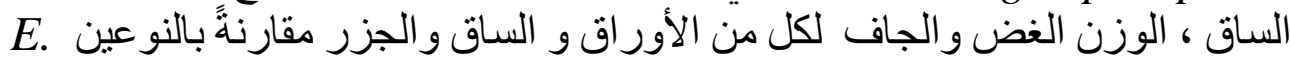
E. camaldulensis citriodora ، camaldulensis أعلى القيم لمحتوى أجزاء النبات المختلفة من النسبة المئوية لعناصر النتروجين

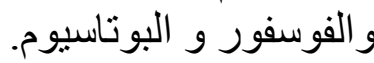




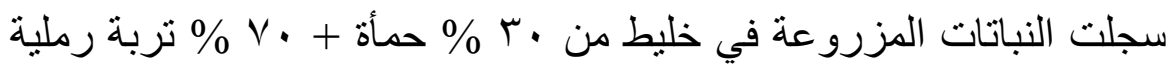

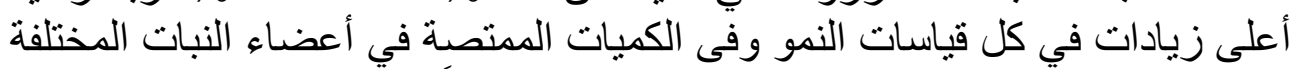

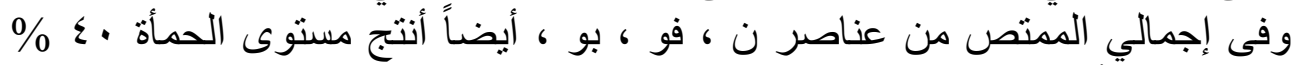

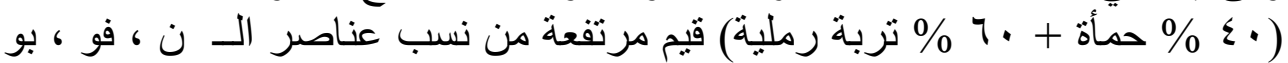
فى أعضاء النبات المختلفة.

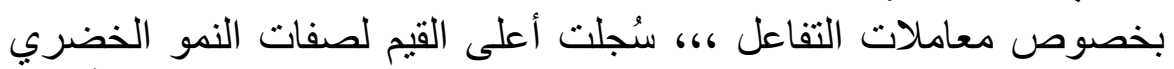

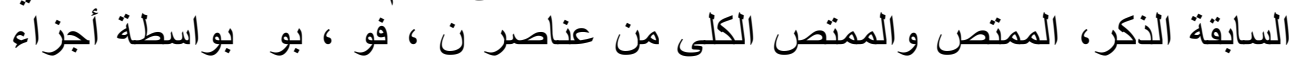

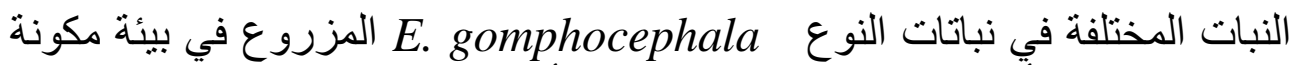

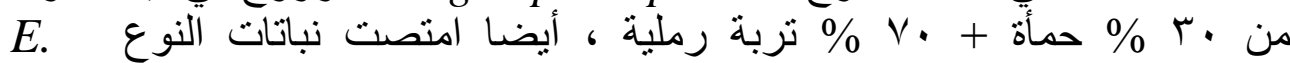
camaldulensis

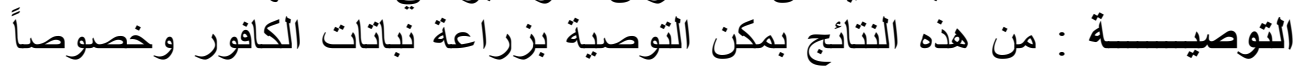
النوع Eomphocephala go في الأر اضي الرملية حديثة الاستصلاح بعد إمدادها

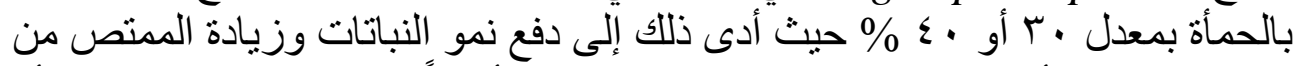

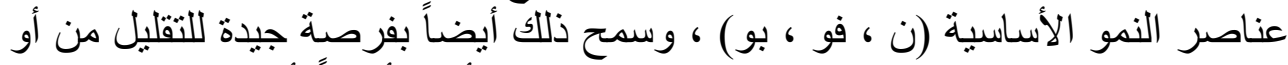

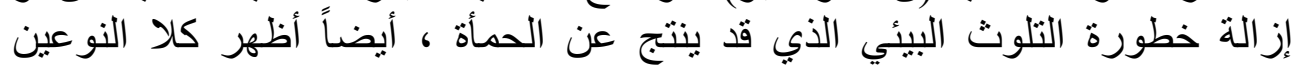
E. citriodora ، E. camaldulensis المزودة بالحمأة. 